\title{
PENGARUH PEMBELAJARAN KEWIRAUSAHAAN, MOTIVASI BERWIRAUSAHA DAN STATUS SOSIAL EKONOMI ORANG TUA TERHADAP MINAT BERWIRAUSAHA MAHASISWA ANGKATAN 2016 PROGRAM STUDI PENDIDIKAN EKONOMI FAKULTAS EKONOMI UNIVERSITAS NEGERI SURABAYA
}

\author{
Triana Dewi, Waspodo Tjipto Subroto \\ Program Studi Pendidikan Ekonomi Fakultas Ekonomi Universitas Negeri Surabaya \\ Email: trianadewi16080554006@mhs.unesa.ac.id
}

\begin{abstract}
Abstrak
Tujuan dari penelitian ini adalah untuk menganalisis apakah terdapat pengaruh pembelajaran kewirausahaan, motivasi berwirausaha dan status sosial ekonomi orang tua terhadap minat berwirausaha mahasiswa angkatan 2016 program studi pendidikan ekonomi fakultas ekonomi Universitas Negeri Surabaya. Subjek penelitian dalam penelitian ini adalah seluruh mahasiswa angkatan 2016 program studi pendidikan ekonomi fakultas ekonomi Universitas Negeri Surabaya yang telah menempuh matakuliah kewirausahaan dengan jumlah 68 mahasiswa. Data dikumpulkan dengan instrumen kuisioner. Analisis data dalam penelitian ini menggunakan regresi linier berganda. Hasil dari penelitian ini menunjukkan bahwa (1) Pembelajaran kewirausahaan tidak berpengaruh terhadap minat berwirausaha mahasiswa. (2) Motivasi berwirausaha berpengaruh terhadap minat berwirausaha mahasiswa. (3) Status sosial ekonomi orang tua tidak berpengaruh terhadap minat berwirausaha mahasiswa. (4) Pembelajaran kewirausahaan, motivasi berwirausaha dan status sosial ekonomi orang tua secara simultan berpengaruh terhadap minat berwirausaha mahasiswa.
\end{abstract}

Kata Kunci: Pembelajaran kewirausahaan, motivasi berwirausaha, status sosial ekonomi orang tua, minat berwirausaha

\begin{abstract}
The purpose of this study was to analyze whether there is an influence of entrepreneurship learning, entrepreneurship motivation and socio economic status of parents on the interest entrepreneurship students for the 2016 class of economic education courses at the Faculty of Economics Surabaya State University. The research subjects in this study were all 2016 class year students of the economic education program at the Faculty of Economics, Surabaya State University who had taken entrepreneurship courses with a total of 68 students. Data was collected by questionnaire instrument. Data analysis in this study uses multiple linear regression. The results of this study indicate that (1) Entrepreneurship learning has no effect on interest entrepreneurship. (2) Entrepreneurship motivation influences student interest in entrepreneurship. (3) Socio economic status of parents does not affect the student interest in entrepreneurship. (4) Learning entrepreneurship, entrepreneurship motivation and socio economic status of parents simultaneously influence student interest entrepreneurship.

Keywords: Entrepreneurship Learning, Entrepreneurship Motivation, Socio Economic Status Of Parents, Interest Entrepreneurship
\end{abstract}

\section{PENDAHULUAN}

Pengangguran menjadi masalah serius yang perlu segera diselesaikan, mengingat angka pengangguran di Indonesia pada masa ini cukup tinggi. Angka pengangguran di Indonesia sebesar 5,01\%, per Juni 2019 Indonesia menduduki posisi kedua setelah Filipina dengan jumlah pengangguran terbanyak sebesar 5,1\% (Adharsyah, 2019). Hal ini menunjukkan bahwa tingkat pengangguran di Indonesia per Juni 2019 mencapai angka $5,01 \%$ yang berada di urutan terbesar kedua setelah Filipina dengan tingkat pengangguran sebesar $5,1 \%$.

Pada dasarnya, kenaikan jumlah penduduk akan mempengaruhi pertumbuhan penduduk akibatnya membuat jumlah angkatan kerja semakin tinggi setiap tahunnya. Kuantitas lapangan pekerjaan dan pengangguran tidak seimbang sehingga diperlukan adanya perluasan lapangan pekerjaan agar dapat menekan jumlah penggangguran, menjadi pengangguran bukanlah suatu pilihan akan tetapi pengangguran terjadi karena 
mereka belum memiliki kesempatan atau peluang untuk bekerja.

Di masa ini, persaingan dalam mencari pekerjaan semakin ketat, pernyataan tersebut diperkuat dengan penelitian Wiradinata dan Candi (2018) yang menyatakan jumlah pengangguran di Indonesia semakin banyak sehingga menyebabkan sulitnya dalam mendapatkan pekerjaan karena persaingan untuk memperoleh pekerjaan semakin sulit dan ketat, hal inilah yang membuat jumlah pengangguran terus meningkat.

Menurut data dari Badan Pusat Statistik (BPS) pengangguran lulusan sarjana pada Februari 2019 besarnya $6,24 \%$ (BPS, 2019). Setiap tahunnya perguruan tinggi meluluskan banyak mahasiswa hal ini membuat jumlah pengangguran lulusan sarjana meningkat.

Menurut penelitian yang telah dilakukan oleh Hanum (2014) Jika lulusan-lulusan diploma dan sarjana mempunyai jiwa entrepreneur maka mereka tidak akan mungkin menganggur. Sehingga untuk mengatasi ketidakseimbangan antara jumlah lapangan pekerjaan dengan jumlah pengangguran lulusan sarjana pemerintah berupaya untuk mendorong dan menumbuhkan minat mahasiswa untuk berwirausaha. Faktor-faktor yang berpengaruh pada minat berwirausaha meliputi pengetahuan kewirausahaan, motivasi, status sosial ekonomi orang tua dan self efficacy (Jailani, Rusdarti, \& Sudarma, 2017).

Pengetahuan kewirausahaan dapat diperoleh mahasiswa melalui pendidikan formal yaitu dengan adanya pembelajaran kewirausahaan pada perguruan tinggi, pembelajaran kewirausahaan adalah upaya pemerintah untuk mendorong minat mahasiswa berwirausaha, upaya ini dilakukan agar dapat menggerakkan mahasiswa untuk berwirausaha, dimana apabila mahasiswa telah lulus dari universitas, mereka bisa menjadi seseorang yang mampu menciptakan kesempatan kerja bukan untuk mencari kerja, sehingga hal ini dapat merubah pola pikir mahasiswa. Pembelajaran kewirausahaan diharapkan dapat menumbuhkan energi wirausaha, berkarya, berdikari, dan membantu perekonomian negara (Tiara \& Nurnida, 2017). Hal ini berarti dengan adanya pembelajaran kewirausahaan dapat membangun semangat dan etos kerja menjadi wirausaha khususnya pada kalangan terdidik yaitu diploma dan sarjana dengan harapan dapat mengurangi jumlah pengangguran, sehingga menjadi wirausaha bisa dijadikan sebagai pilihan karir. Pembelajaran kewirausahaan akan menumbuhkan minat mahasiswa untuk berwirausaha dan mereka dapat menuangkan ide kreatifnya dalam bentuk wirausaha hal ini sesuai dengan hasil penelitian Wibowo (2011) yang menyatakan pembelajaran kewirausahaan berpengaruh terhadap minat berwirausaha.
Seorang wirausaha merupakan penyedia dan penyalur transformasi yang memperkenalkan perbaikan dan perubahan semacam sistem produksi, sistem penjualan, barang dan jenis alat kerja baru (Aidha, 2016). Hal tersebut diperkuat dengan pernyataan Ketua Dewan Komisioner Otoritas Jasa Keuangan (OJK) Wimboh Santoso (04/10/19) ketika seminar Millenial Fest Industry 4.0 bertajuk "Kaum Milenial dan Industri 4.0" bahwa kewirausahaan wajib didorong untuk meningkatkan pertumbuhan ekonomi nasional (Dahono, 2019). Dari pernyataan tersebut bisa ditarik kesimpulan jika seorang wirausaha yaitu agen perubahan yang dapat memberikan dampak yang positif terhadap perekonomian, apabila jumlah mahasiswa yang berwirausaha tinggi maka tingkat peluang kerja yang tersedia juga akan tinggi karena semakin tinggi jumlah mahasiswa yang berwirausaha maka akan tersedia banyak kesempatan kerja baru, hal ini berkontribusi besar untuk membantu pemerintah mengurangi jumlah pengangguran. Namun, di dalam penelitian Majdi (2012) menyatakan bahwa pembelajaran kewirausahaan tidak berpengaruh terhadap minat berwirausaha, ada faktor-faktor lain yang lebih berpengaruh terhadap minat berwirausaha yaitu motivasi berwirausaha dan teman sebaya.

Di Program Studi Pendidikan Ekonomi Fakultas Ekonomi Universitas Negeri Surabaya mata kuliah kewirausahaan di tempuh di semester lima, dengan kisaran bobot persemester 2 SKS sehingga terjadi tatap muka di kelas 2 jam perminggu, mata kuliah ini wajib di tempuh mahasiswa hal tersebut sebagai upaya agar mahasiswa dapat lebih mengenal dunia wirausaha, dengan adanya pembelajaran kewirausahaan mahasiswa akan dapat mempelajari dan memahami baik secara teoritis maupun praktiknya dimana para mahasiswa diharuskan mampu menciptakan suatu barang atau jasa yang mempunyai nilai jual bersama dengan teman satu kelompoknya beserta dalam pemasaran dan penjualannya sehingga bukan hanya pengetahuan saja yang diperoleh tetapi juga pengalaman, mahasiswa akan dapat menerapkannya dalam kehidupan nyata.

Berdasarkan pra penelitian melalui pengamatan dan wawancara kepada mahasiswa program studi pendidikan ekonomi angkatan 2016, bahwa ketika mata kuliah kewirausahaan telah selesai mahasiswa tidak melanjutkan usaha yang telah dilakukan, mahasiswa membuat usaha untuk memenuhi tugas mata kuliah kewirausahaan, mahasiswa cenderung takut untuk berwirausaha karena dibayangi oleh resiko ketidakberhasilan atau kerugian yang mungkin terjadi dan merasa kurang terampil dalam membuat dan mengelola suatu usaha. Hal ini menunjukkan bahwa motivasi berwirausaha mahasiswa masih rendah sedangkan menurut penelitian yang dilakukan oleh Wiradinata dan Candi (2018) untuk dapat 
menumbuhkan minat berwirausaha, seseorang perlu memiliki motivasi akan berwirausaha.

Status sosial ekonomi orang tua salah satu keadaan dalam bagian keluarga yang memegang pengaruh besar dalam mengoptimalkan potensi dan minat yang dimiliki anak terutama dalam minat berwirausaha. Menurut Wulandari (2013) status sosial ekonomi orang tua yang cukup dan kurang mengalami tekanan-tekanan fundamental maka orang tuanya dapat mencurahkan perhatian yang lebih mendalam pada masa depan anakanaknya agar dapat memperoleh masa depan yang lebih cerah dengan memenuhi sarana dan kelengkapan yang memadai khususnya dalam berwirausaha. Dalam penelitian Jailani, Rusdarti dan Sudarma (2017) menyatakan bahwa ada pengaruh status sosial ekonomi orang tua terhadap minat berwirausaha yang berarti bahwa semakin tinggi status sosial ekonomi orang tua maka semakin tinggi pengaruhnya terhadap minat berwirausaha. Pernyataaan tersebut sejalan dengan penelitian Candra (2015) bahwa terdapat pengaruh status sosial ekonomi orang tua terhadap minat berwirausaha, orang tua yang mempunyai status sosial ekonomi yang tinggi akan mampu mendorong minat anak untuk berwirausaha. Akan tetapi, menurut (Umam \& Syah, 2018) status sosial ekonomi orang tua tidak berpengaruh terhadap minat berwirausaha, menurutnya ada faktor lainnya yang mempengaruhi minat berwirausaha yakni, rasa percaya diri, teman sebaya dan media sosial.

Berdasarkan pra penelitian yang telah dilakukan oleh peneliti melalui wawancara kepada mahasiswa program studi pendidikan ekonomi angkatan 2016 diperoleh informasi bahwa orang tua mahasiswa mengenyam pendidikan terakhir pada jenjang SMA/SMK/Sederajat dan memiliki penghasilan dibawah Rp2.000.000,00 sehingga orang tua belum dapat mendukung mahasiswa secara financial dalam berwirausaha

Dari permasalahan yang telah dipaparkan di atas maka peneliti akan melaksanakan penelitian lebih mendalam mengenai pengaruh pembelajaran kewirausahaan, motivasi berwirausaha dan status sosial ekonomi orang tua terhadap minat berwirausaha. Tujuan dari penelitian ini yakni untuk menganalisis ada tidaknya pengaruh antara pembelajaran kewirausahaan, motivasi berwirausaha dan status sosial ekonomi orang tua terhadap minat berwirausaha mahasiswa angkatan 2016 program studi pendidikan ekonomi Universitas Negeri Surabaya.

\section{METODE}

Dalam penelitian ini menggunakan jenis penelitian asosiatif kausal dengan pendekatan kuantitatif. Teknik pengambilan sampel menggunakan teknik sampling jenuh sehingga seluruh jumlah populasi dalam penelitian ini digunakan sebagai sampel yaitu prodi pendidikan ekonomi angkatan 2016 fakultas ekonomi Universitas Negeri Surabaya yang berjumlah 68 mahasiswa. Dalam penelitian ini terdiri dari variabel bebas dan variabel terikat, variabel bebasnya meliputi pembelajaran kewirausahaan, motivasi berwirausaha dan status sosial ekonomi orang tua. Sedangkan dalam variabel terikatnya meliputi minat berwirausaha.

Teknik pengumpulan data menggunakan kuisioner, wawancara dan dokumentasi. Pada minat berwirausaha menggunakan indikator prestige sosial, tantangan pribadi, menjadi bos, inovasi, kepemimpinan, fleksibilitas dan keuntungan (Utoyo 2010), pada variabel pembelajaran kewirausahaan menggunakan indikator tujuan pendidikan, sarana dan prasarana, materi dan metode pengajaran (Widayahwati, 2019), pada variabel motivasi berwirausaha menggunakan indikator adanya hasrat dan keinginan berhasil, adanya dorongan dan kebutuhan dalam berwirausaha, adanya harapan dan cita-cita masa depan, adanya penghargaan dalam berwirausaha, dan adanya keinginan yang menarik dalam berwirausaha (Qoonitah, 2018), Pada variabel status sosial ekonomi orang tua menggunakan indikator pendidikan terakhir orang tua dan penghasilan orang tua (Khairul dan Syah, 2018). Teknik analisis data menggunakan uji regresi linier berganda.

\section{HASIL DAN PEMBAHASAN \\ 1. Uji Asumsi Klasik}

Dalam uji normalitas diketahui nilai Asymp.Sig sebesar 0,677 sehingga 0,677>0,05 artinya data sudah terdistribuai secara normal. Uji multikolinearitas menunjukkan besar nilai toleransi $\geq 0,10$ dimana nilai tolerance X1 $(0,906) \geq 0,10, \mathrm{X} 2(0,905) \geq 0,10$ dan X3 $(0,990) \geq 0,10$ selanjutnya pada nilai VIF menunjukkan jika VIF $\leq 10$ yaitu pada X1 $(1,104) \leq 10$, X2 $(1,105) \leq$ 10 , dan $\mathrm{X} 3(1,010) \leq 10$ maka bisa dinyatakan model regresi dalam penelitian ini antar variabel bebasnya tidak ada korelasi. Pada uji heteroskedastisitas menunjukkkan besar signifikansi pada masing-masing variabel yaitu dalam X1 $(0,332)>0,05, \quad \mathrm{X} 2(0,129)>0,05$ dan X3 $(0,496)>0,05$ maka dalam permodelan regresi tidak mengandung heteroskedastisitas. Pada uji linieritas menunjukkan besar Sig dari Deviation from Linearity pada setiap variabel bebas dan variabel terikatnya mempunyai hasil > 0,05 sehingga bisa dinyatakan asumsi linieritas terpenuhi dan mempunyai tingkat hubungan yang linier.

\section{Hasil Uji Analisis Regresi Linier Berganda}

Tabel 4 Hasil Uji Analisis Regresi Linier Berganda 


\begin{tabular}{|c|c|c|c|c|}
\hline \multirow[t]{2}{*}{ Model } & \multicolumn{2}{|c|}{ Coefficients } & & \\
\hline & B & $\begin{array}{l}\text { Std. } \\
\text { Error }\end{array}$ & & \\
\hline 1 (Constatnt) & 37.392 & 7.320 & 5.108 & .000 \\
\hline $\mathrm{X} 1$ & .028 & .149 & .189 & .850 \\
\hline $\mathrm{X} 2$ & 1.221 & .159 & 7.671 & .000 \\
\hline X3 & -.186 & .342 & -.545 & .588 \\
\hline
\end{tabular}

Sumber: Data Diolah Peneliti (2020)

a. Uji T

Berdasarkan tabel 4 di atas menunjukkan bahwa:

1. Variabel X1 memiliki nilai signifikansi $0,850>$ 0,05 maka tidak ditemukan pengaruh variabel pembelajararan kewirausahaan (X1) terhadap minat berwirausaha (Y) sehingga Ha ditolak.

2. Variabel $\mathrm{X} 2$ memiliki nilai signifikansi $0,000<$ 0,05 maka ditemukan pengaruh secara parsial sebesar 7,671 variabel motivasi berwirausaha (X2) terhadap minat berwirausaha (Y) sehingga $\mathrm{Ha}$ diterima.

3. Variabel X3 memiliki nilai signifikansi $0,588>$ 0,05 maka tidak ditemukan pengaruh variabel status sosial ekonomi orang tua (X3) terhadap minat berwirausaha (Y) sehingga Ha ditolak

\section{b. Koefisien Determinan $\left(\mathbf{R}^{2}\right)$}

Hasil analisis data menjelaskan jika nilai Adjusted $\mathrm{R}$ Square yaitu 0,488 , artinya kontribusi variabel pembelajaran kewirausahaan (X1), motivasi berwirausaha (X2) dan status sosial ekonomi orang tua (X3) secara simultan berpengaruh terhadap minat berwirausaha mahasiswa (Y) sebesar 0,488 atau 48,8\% dan sebesar $51,2 \%$ dipengaruhi oleh variabel lain yang tidak ada dalam penelitian ini.

\section{Pembahasan}

1. Pengaruh Pembelajaran Kewirausahaan Terhadap Minat Berwirausaha Mahasiswa Angkatan 2016 Prodi Pendidikan Ekonomi Fakultas Ekonomi Universitas Negeri Surabaya

Berdasarkan analisis data yang telah dilakukan, dalam pengujian hipotesis pertama menyatakan jika pembelajaran kewirausahaan tidak berpengaruh terhadap minat mahasiswa berwirausaha, karena setelah dilakukan analisis data secara statistik tidak terbukti dan ditolak. Tinggi rendahnya minat berwirausaha mahasiswa tidak dapat dijelaskan dengan baik oleh pembelajaran kewirausahaan.

Hasil dalam penelitian ini tidak sejalan dengan hasil penelitian yang telah dilakukan Hanum (2014) bahwa mata kuliah kewirausahaan mendukung minat mahasiswa untuk berwirausaha. Tiara dan Nurnida (2017) juga menghasilkan kesimpulan yang sama bahwa mata kuliah kewirausahaan berpengaruh terhadap minat mahasiswa untuk berwirausaha. Tetapi dalam penelitian Setiawan (2018) menyatakan jika pembelajaran kewirausahaan tidak berpengaruh terhadap minat berwirausaha. Hal tersebut didukung oleh penelitian Trisnawati (2014) menyatakan jika pembelajaran kewirausahaan tidak memiliki pengaruh terhadap minat berwirausaha. Penelitian ini mendukung teori lambing (Suryana, 2009) bahwa kebanyakan seseorang menjadi menjadi wirausaha karena didasari oleh pengalaman sehingga ia memiliki jiwa dan watak kewirausahaan. Oleh karena itu, pembelajaran saja tidak cukup untuk membekali mahasiswa berminat berwirausaha.

Tidak signifikannya pengaruh variabel pembelajaran kewirausahaan terhadap minat berwirausaha diduga karena disebabkan faktorfaktor lain. Dari hasil penemuan peneliti faktor lain yang mempengaruhi adalah faktor motivasi, motivasi adalah gejala psikis yang dapat mendorong dan membentuk persepsi serta perilaku mahasiswa terkait kewirausahaan, apabila motivasi berwirausaha mahasiswa telah aktif maka mereka akan tergerak untuk berwirausaha, hal ini sesuai dengan penelitian Majdi (2012) yang menyatakan bahwa tidak berpengaruhnya pembelajaran kewirausahaan terhadap minat berwirausaha dikarenakan adanya faktor lain yang mempengaruhi yakni motivasi berwiausaha.

Pengukuran variabel pembelajaran kewirausahaan dalam penelitian ini menggunakan indikator tujuan pendidikan, sarana dan prasarana, materi dan metode pengajaran. Berdasarkan hasil penelitian dalam pembelajaran kewirausahaan menunjukkan jika sebesar $35,2 \%$ responden menyatakan bahwa sarana dan prasarana yang ada belum maksimal dalam mendukung minat berwirausaha, dimana fasilitas perpustakaan belum dapat memberikan dan menambah pengetahuan tentang kewirausahaan dan kurang optimalnya fasilitas lainnya seperti akses internet, seminar dan pelatihan kewirausahaan di kampus. Hal ini, sesuai dengan penelitian yang telah dilakukan Setiawan (2018) tidak berpengaruhnya pembelajaran kewirausahaan terhadap minat berwirausaha diantaranya disebabkan adanya $18 \%$ responden yang mengatakan fasilitas dikampus belum dapat memberikan pengetahuan secara maksimal tentang kewirausahaan sehingga dengan adanya pembelajaran kewirausahaan dengan fasilitas yang lengkap dan nyaman di kampus akan dapat menumbuhkan minat berwirausaha pada mahasiswanya. 
2. Pengaruh Motivasi Berwirausaha Terhadap Minat Berwirausaha Mahasiswa Angkatan 2016 Prodi Pendidikan Ekonomi Fakultas Ekonomi Universitas Negeri Surabaya

Berdasarkan analisis data yang telah dilaksanakan dalam pengujian hipotesis kedua menyatakan jika motivasi berwirausaha berpengaruh signifikan terhadap minat mahasiswa berwirausaha sehingga pernyataan pengaruh motivasi berwirausaha terhadap minat berwirausaha mahasiswa diterima karena setelah dilakukan analisis data secara statistik dapat dibuktikan dimana motivasi berwirausaha mampu menjelaskan dengan baik tinggi rendahnya minat berwirausaha mahasiswa.

Hasil pengujian dalam penelitian ini didukung Yulianti (2013) yang menyatakan motivasi berwirausaha berpengaruh secara positif dan signifikan terhadap minat berwirausaha. Motivasi berwirausaha berpengaruh signifikan terhadap minat berwirausaha (Wiradinata \& Candi, 2018). Penelitian ini mendukung teori Baum, Frese, dan Baron (Rosmiati, Junias, \& Munawar, 2015) jika motivasi berwirausaha merupakan motivasi yang difokuskan meraih tujuan kewirausahaan, tujuan yang mengaitkan perkenalan dan pengeksploitasian terhadap kesempatan usaha. Sehingga apabila mahasiswa mempunyai motivasi yang kuat dalam berwirausaha maka dapat berpengaruh terhadap minat berwirausaha.

Pengukuran variabel motivasi berwirusaha dalam penelitian ini menggunakan indikator adanya hasrat dan keinginan berhasil, adanya keinginan yang menarik dalam berwirausaha, adanya harapan dan cita-cita masa depan, adanya dorongan dan kebutuhan dalam berwirausaha, adanya penghargaan dalam berwirausaha. Hasil penelitian menunjukkan jika sebesar 47,1\% mahasiswa mengatakan jika mereka mempunyai motivasi untuk menjadi wirausaha karena mereka memiliki harapan yang tinggi agar sukses di masa depan dalam bidang wirausaha dan sebesar $44,1 \%$ ingin mendapatkan pengalaman sebanyak mungkin dalam hal berwirausaha, pengalaman adalah guru terbaik untuk menuju kesuksesan dengan adanya pengalaman maka setiap individu akan lebih berhati-hati agar tidak mengulangi kesalahan yang sama, apabila mahasiswa telah memiliki banyak pengalaman dalam hal berwirausaha maka mereka akan dapat bertanggung jawab dan menganalisa peluang kewirausahaan dengan tepat sehingga mereka akan meraih kesuksesan dalam berwirausaha.

\section{Pengaruh Status Sosial Ekonomi Orang Tua Terhadap Minat Berwirausaha Mahasiswa Angkatan 2016 Prodi Pendidikan Ekonomi Fakultas Ekonomi Universitas Negeri Surabaya}

Pengujian hipotesis ketiga menyatakan jika status sosial ekonomi orang tua tidak berpengaruh terhadap minat mahasiswa berwirausaha, karena setelah dilakukan analisis data secara statistik tidak terbukti dan ditolak. Status sosial ekonomi orang tua tidak mampu menjelaskan dengan baik tinggi rendahnya minat berwirausaha mahasiswa. Dari hasil penemuan peneliti terdapat faktor lain yang mempengaruhi minat mahasiswa berwirausaha selain status sosial ekonomi orang tua yakni motivasi berwirausaha, motivasi berwirausaha ialah energi penggerak dalam diri seseorang yang mampu mendorong kegiatan berwirausaha. Selain itu, faktor lain berupa kepercayaan diri, percaya diri menunjukkan kekuatan bagi wirausaha, percaya diri yang kuat akan mendorong wirausaha untuk lebih maju, hal tersebut didukung oleh Khairul \& Syah (2018) yang menyatakan bahwa faktor lain yang mempengaruhi minat berwirausaha yaitu sikap percaya diri.

Hasil dalam penelitian ini tidak selaras dengan penelitian Jailani, Rusdarti dan Sudarma (2017) yang menyatakan bahwa ada pengaruh status sosial ekonomi orang tua terhadap minat berwirausaha yang berarti bahwa semakin tinggi status sosial ekonomi orang tua maka semakin tinggi pengaruhnya terhadap minat berwirausaha, penelitian Candra (2015) menyatakan bahwa terdapat pengaruh status sosial ekonomi orang tua terhadap minat berwirausaha orang tua yang memiliki status sosial ekonomi yang tinggi akan mampu membangkitkan minat anak untuk berwirausaha. Namun dalam penelitian yang dilakukan oleh Widayahwati (2019) menyatakan bahwa tidak ada pengaruh status sosial ekonomi orang tua terhadap minat berwirausaha, hal tersebut didukung oleh Khairul \& Syah (2018) menyatakan bahwa tidak ada pengaruh status sosial ekonomi orang tua terhadap minat berwirausaha, menurutnya orang tua yang berpendidikan tinggi dan berpenghasilan besar cenderung lebih menjadikan dirinya sebagai pemberi dukungan terhadap apapun minat dan keinginan anaknya. Sehinggga orang tua yang memiliki penghasilan dan pendidikan yang tinggi akan cenderung memberikan dukungan yang optimal baik secara moril maupun materil terhadap segala apapun minat anaknya

Hasil penelitian ini menjelaskan jika sebagian besar pendidikan orang tua mahasiswa berada pada jenjang SMA/SMK/Sederajat dan sebagian besar 
penghasilan ayah mahasiswa berkisar Rp2.000.000,00 - Rp5.000.000,00 serta sebagian besar penghasilan ibu mahasiswa berada dibawah Rp2.000.000,00. Berdasarkan distribusi kecenderungan variabel status sosial ekonomi orang tua termasuk kategori yang sedang, sehingga orang tua mahasiswa belum dapat memberikan dukungan financial secara maksimal untuk mahasiswa dapat berwirausaha.

\section{Pengaruh Pembelajaran Kewirausahaan, Motivasi} Berwirausaha Dan Status Sosial Ekonomi Orang Tua Terhadap Minat Berwirausaha Mahasiswa Angkatan 2016 Prodi Pendidikan Ekonomi Fakultas Ekonomi Universitas Negeri Surabaya

Berdasarkan hasil analisis yang telah dilaksanakan oleh peneliti ditemukan hasil bahwa pembelajaran kewirausahaan, motivasi berwirausaha dan status sosial ekonomi orang tua berpengaruh secara simultan sebesar $48,8 \%$ terhadap minat berwirausaha mahasiswa angkatan 2016 Prodi Pendidikan Ekonomi Fakultas Ekonomi Universitas Negeri Surabaya dan sisanya dipengaruhi oleh faktor lain di luar penelitian sebesar 51,2\%.

Penelitian ini sejalan dengan penelitian yang telah dilakukan oleh Jailani, Rusdarti dan Sudarma (2017) yang menyatakan bahwa pembelajaran kewirausahaan, motivasi berwirausaha dan status sosial ekonomi orang tua berpengaruh terhadap minat berwirausaha. Tidak signifikannya pengaruh variabel pembelajaran kewirausahaan terhadap minat berwirausaha diduga karena disebabkan faktor-faktor lain.

Dari hasil penemuan peneliti faktor lain yang mempengaruhi adalah faktor motivasi dan faktor percaya diri, motivasi adalah gejala psikis yang dapat mendorong dan membentuk persepsi serta perilaku mahasiswa terkait kewirausahaan, apabila motivasi berwirausaha mahasiswa telah aktif maka mereka akan tergerak untuk berwirausaha, hal ini sesuai dengan penelitian Majdi (2012) yang menyatakan bahwa tidak berpengaruhnya pembelajaran kewirausahaan terhadap minat berwirausaha dikarenakan adanya faktor lain yang mempengaruhi yakni motivasi berwiausaha. Motivasi berwirausaha merupakan sebuah sarana yang penting untuk dapat menggerakkan individu berwirausaha, dengan adanya motivasi yang kuat maka individu akan bersungguh-sungguh untuk mengaktualisasi potensi yang dimiliki, orang yang berhasil adalah orang yang memiliki motivasi yang tinggi karena motivasi akan mendorong perilaku mereka untuk sukses. Sedangkan faktor Percaya diri menunjukkan kekuatan bagi wirausaha, percaya diri yang kuat akan mendorong wirausaha untuk lebih maju, hal tersebut didukung oleh Khairul \& Syah (2018) yang menyatakan bahwa faktor lain yang mempengaruhi minat berwirausaha yaitu sikap percaya diri. Pada penelitian ini motivasi berwirausaha merupakan variabel yang paling kuat dalam mempengaruhi minat berwirausaha dikarenakan ketika dilakukan analisis secara parsial pembelajaran kewirausahaan dan status sosial ekonomi orang tua tidak berpengaruh terhadap mnat berwirausaha dan hanya motivasi berwirausaha yang berpengaruh terhadap minat berwirausaha. Namun setelah dilakukan analisis secara simultan variabel pembelajaran kewirausahaan, motivasi berwirausaha dan status sosial ekonomi orang tua berpengaruh terhadap minat berwirausaha. Pada variabel motivasi berwirausaha peneliti memperoleh penemuan bahwa sebesar $47,1 \%$ mahasiswa mengatakan jika mereka mempunyai motivasi untuk menjadi wirausaha karena mereka memiliki harapan yang tinggi agar sukses di masa depan dalam bidang wirausaha dan sebesar $44,1 \%$ ingin mendapatkan pengalaman sebanyak mungkin dalam hal berwirausaha, pengalaman adalah guru terbaik untuk menuju kesuksesan dengan adanya pengalaman maka setiap individu akan lebih berhatihati agar tidak mengulangi kesalahan yang sama, apabila mahasiswa telah memiliki banyak pengalaman dalam hal berwirausaha maka mereka akan dapat bertanggung jawab dan menganalisa peluang kewirausahaan dengan tepat sehingga mereka akan meraih kesuksesan dalam berwirausaha.

Pada pembelajaran kewirausahaan peneliti mendapatkan penemuan bahwa sebesar 35,2\% responden menyatakan sarana dan parasarana yang ada di kampus belum mampu memberikan dan menambah pengetahuan tentang kewirausahaan dimana kurang optimalnya fasilitas seperti perpustakaan, akses internet, seminar dan pelatihan kewirausahaan di kampus. Jika jumlah dan variasi buku kewirausahaan memadai dan akses intenet mudah maka mahasiswa akan dapat dengan mudah memperoleh dan mengakses informasi terkait pembelajaran kewirausahaan dari berbagai sumber. Disamping itu, jika sering diadakan seminar dan pelatihan maka mahasiswa akan dapat memperoleh pengetauan baru terutama dalam mengatasi berbagai permasalahan yang ditemui dalam kegiatan berwirausaha dan mahasiswa akan dapat mengetahui berbagai jenis wirausaha yang memiliki prospek cerah dan menguntungkan pada masa ini. Jika sarana dan prasarana yang ada lengkap maka akan dapat memudahkan mahasiswa untuk memperoleh 
pengetahuan dan pengalaman yang maksimal tentang wirausaha karena fasilitas yang lengkap dan nyaman akan dapat menumbuhkan minat berwirausaha pada mahasiswa.

Pada variabel status sosial ekonomi orang tua peneliti memperoleh penemuan jika distribusi kecenderungan status sosial ekonomi orang tua termasuk kategori yang sedang, sehingga orang tua mahasiswa belum dapat memberikan dukungan financial secara maksimal untuk mahasiswa dapat berwirausaha.

Maka hasil analisis menunjukkan bahwa mahasiswa angkatan 2016 Prodi Pendidikan Ekonomi Fakultas Ekonomi Universitas Negeri Surabaya memiliki minat berwirausaha, mahasiswa adalah kaum intelektual yang dapat memberikan inovasi-inovasi baru sehingga diharapkan minat mahasiswa dalam berwirausaha mendapatkan dukungan dengan baik sehingga dapat menggerakkan mahasiswa untuk segera memulai suatu usaha yang di cita-citakan.

\section{PENUTUP}

\section{Simpulan}

Berdasarkan data yang diperoleh dari hasil analisis yang telah dilaksanakan oleh peneliti maka dapat ditarik kesimpulan: (1) Tidak terdapat pengaruh variabel pembelajaran kewirausahan terhadap minat berwirausaha mahasiswa angkatan 2016 Prodi Pendidikan Ekonomi Fakultas Ekonomi Universitas Negeri Surabaya. (2) Terdapat pengaruh variabel motivasi berwirausaha terhadap minat berwirausaha mahasiswa angkatan 2016 Prodi Pendidikan Ekonomi Fakultas Ekonomi Universitas Negeri Surabaya. (3) Tidak terdapat pengaruh variabel status sosial ekonomi orang tua terhadap minat berwirausaha mahasiswa angkatan 2016 Prodi Pendidikan Ekonomi Fakultas Ekonomi Universitas Negeri Surabaya. (4) Terdapat pengaruh pembelajaran kewirausahaan, motivasi berwirausaha dan status sosial ekonomi orang tua terhadap minat berwirausaha mahasiswa angkatan 2016 Prodi Pendidikan Ekonomi Fakultas Ekonomi Universitas Negeri Surabaya.

\section{Saran}

Berdasarkan pemaparan hasil penelitian di atas peneliti berusaha memberikan saran sebagai berikut yaitu : (1) Setelah lulus mahasiswa dapat memanfaatkan peluang untuk menciptakan suatu pekerjaan dibandingkan mencari pekerjaan. (2) Diperlukan adanya peningkatan variasi metode pembelajaran, sarana dan prasarana yang menunjang aktivitas berwirausaha seperti mengadakan seminar dan pelatihan kewirausahaan. (3) Bagi orang tua mahasiswa diharapkan dapat memberikan pemahaman tentang wirausaha dari dini dan dapat mendukung serta mendorong anak untuk mengembangkan minat yang dimiliki secara optimal baik dalam segi moril maupun materil agar anaknya dapat mengasah kemampuannya dalam berwirausaha maupun tidak. (4) Penelitian ini memberikan wawasan terkait pengaruh pembelajaran kewirausahaan, motivasi berwirausaha dan status sosial ekonomi orang tua secara bersama-sama terhadap minat berwirausaha mahasiswa angkatan 2016 Prodi Pendidikan Ekonomi Fakultas Ekonomi Universitas Negeri Surabaya sebesar 48,88\% sehingga sisanya dipengaruhi oleh faktor lain yaitu sebesar 51,2\%. Maka dari itu, diharapkan dalam penelitian berikutnya dapat dijumpai faktor-faktor lainnya yang mempengaruhi minat mahasiswa dalam berwirausaha selain faktor-faktor dalam penelitian ini.

\section{DAFTAR PUSTAKA}

Adharsyah, T. (2019). 74 Tahun Ri Belum Merdeka Dari Pengangguran \& Kemiskinan. Retrieved From Https://Www.Cnbcindonesia.Com/News/20190817 113812-4-92715/74-Tahun-Ri-Belum-MerdekaDari-Pengangguran-Kemiskinan

Aidha, Z. (2016). Pengaruh Motivasi Terhadap Minat Berwirausaha Mahasiswa Fakultas Kesehatan Masyarakat Universitas Islam Negeri Sumatera Utara. Jumantik, 1(1), 42-59.

Bps. (2019). Www.Bps.Go.Id.

Candra, A. (2015). Minat Berwirausaha Di Tinjau Dari Status Sosial Ekonomi Orang Tua Dan Sikap Mandiri Pada Mahasiswa. Naskah Publikasi, 151, 10-17.

HTTPS://DOI.ORG/10.1145/3132847.3132886

Dahono, Y. (2019). Kewirausahaan Kunci Pertumbuhan Ekonomi Indonesia. Retrieved From Https://Www.Beritasatu.Com/Ekonomi/578416/Ek onomi/578416-Ketua-Ojk-Kewirausahaan-KunciPertumbuhan-Ekonomi-Indonesia

Hanum, A. N. (2014). Pengaruh Mata Kuliah Kewirausahaan Terhadap Minat Mahasiswa Menjadi Wirausaha (Studi Kasus PADA Universitas Muhammadiyah Semarang). Ekonomi Dan Pendidikan.

Jailani, M., Rusdarti, \& Sudarma, K. (2017). Pengaruh Kewirausahaan, Motivasi, Sosial Ekonomi Orang Tua Dan Self Efficacy Terhadap Minat Berwirausaha Siswa. Journal OF Economic Education, 6(1), 52-59. HTTPS://DOI.ORG/10.15294/Jeec.V6i1.14701

Majdi, M. Z. (2012). Pengaruh Pembelajaran Kewirausahaan, Internalisasi Nilai Kewirausahaan DI Keluarga Dan Motivasi Minat Kewirausahaan. Jurnal Pendidikan, 7(2), 1-25.

Qoonitah, A. (2018). Pengaruh Pembelajaran Kewirausahaan Dan Motivasi Berwirausaha Terhadap Minat Berwirausaha Mahasiswa 
Pendidikan Ips Fakultas Ilmu Tarbiyah Dan Keguruan Uin Maulana Malik Ibrahim Malang. Skripsi, (1), 43. HTTPS://DOI.ORG/10.1017/Cbo9781107415324.0 04

Rosmiati, R., Junias, D. T. S., \& Munawar, M. (2015). Sikap, Motivasi, Dan Minat Berwirausaha Mahasiswa. Jurnal Manajemen Dan Kewirausahaan (Journal OF Management AND Entrepreneurship), 17(1), 21-30. HTTPS://DOI.ORG/10.9744/JMK.17.1.21-30

Setiawan, D. Y. (2018). Pengaruh Perilaku Proaktif, Lingkungan Keluarga Dan Pendidikan Kewirausahaan Terhadap Minat Berwirausaha Mahasiswa Stie Putra Bangsa Kebumen. Skripsi, 1(1), 1-10. HTTPS://DOI.ORG/10.1037/00223514.51.6.1173

Suryana. (2009). Kewirausahaan, Pedoman Praktis: Kiat DAN Proses Menuju Sukses. Jakarta: Salemba Empat.

Tiara, H. N., \& Nurnida, I. (2017). Pengaruh Mata Kuliah Kewirausahaan Terhadap Minat Berwirausaha Mahasiswa. Jurnal Ecodemica, 1(1), 89-97.

Trisnawati, N. (2014). Pengaruh Pengetahuan Kewirausahaan Dan Dukungan Sosial Keluarga Pada Minat Berwirausaha Siswa Smk Negeri 1 Pamekasan. Jurnal Ekonomi Pendidikan Dan Kewirausahaan, 2.

Umam, K., \& Syah, N. (2018). Pengaruh Status Sosial Ekonomi Orang Tua Terhadap Minat Berwirausaha Mahasiswa Teknik Sipil Program Studi Pendidikan Teknik Bangunan, Fakultas Teknik, Universitas Negeri Padang Cived Issn 2302-3341. Cived Issn: $2302-3341,6(1), 1-4$.

Utoyo, F. (2010). Identifikasi Konsep Diri, Minat Berwirausaha Danciri-Ciri Wirausaha. 40-54.

Wibowo, M. (2011). Pembelajaran Kewirausahaan Dan Minat Wirausaha Lulusan Smk. Jurnal Ekplanasi, 6(September), 109-122.

Widayahwati, D. (2019). Pengaruh Pendidikan Kewirausahaan Dan Status Sosial Ekonomi Orang Tua Terhadap Minat Berwirausaha Siswa. Skripsi.

Wiradinata, T., \& Candi, P. (2018). Pengaruh Motivasi Berwirausaha, Pendidikan Kewirausahaan, Dan Lingkungan Keluarga Terhadap Minat Berwirausaha Mahasiswa Universitas Ciputra. Jurnal Manajemen Dan Start-Up Bisnis Volume, $3(3)$.

Wulandari, R. (2013). Pengaruh Status Sosial Ekonomi Orang Tua Terhadap Minat Berwirausaha Mahasiswa Program Studi Pendidikan Ekonomi. Artikel Penelitian. 